\title{
Device Feasibility Study
}

National Cancer Institute

\section{Source}

National Cancer Institute. Device Feasibility Study. NCI Thesaurus. Code C139174.

An intervention of a device product is being evaluated to determine the feasibility of the product or to test a prototype device and not health outcomes. Such studies are conducted to confirm the design and operating specifications of a device before beginning a full clinical trial. (ClinicalT rials.gov) 